\title{
The role of stable isotopes and mercury concentrations to describe seabird foraging ecology in tropical environments
}

Teresa Catry ${ }^{1 *}$, Jaime A. Ramos ${ }^{1}$, Matthieu Le Corre ${ }^{2}$, Jessica Kojadinovic ${ }^{2,3}$, Paco Bustamante $^{3}$

${ }^{1}$ Institute of Marine Research (IMAR), Department of Zoology, University of Coimbra, 3004-517 Coimbra, Portugal

${ }^{2}$ Laboratoire ECOMAR, Université de la Réunion, 97715 Saint Denis message cedex 9, France

${ }^{3}$ LIENSs, UMR 6250, CNRS - Université de La Rochelle, 2 rue Olympe de Gouges, La Rochelle, 17042 France

*Corresponding author: teresa_catry@yahoo.com 
Abstract: Nitrogen $\left(\delta^{15} \mathrm{~N}\right)$ and carbon $\left(\delta^{13} \mathrm{C}\right)$ stable isotopes and contaminants, such as mercury, have been widely used to characterise foraging ecology of temperate and polar seabirds. In this study, for the first time, we used isotopic signatures and mercury levels of feathers and blood of eight tropical seabird species, that forage in a range-gradient between inshore and offshore areas, to describe the foraging habits of a large tropical seabird community (from two neighbouring islands of the Seychelles archipelago, western Indian Ocean) during both the breeding and interbreeding periods. Overall, we found a high overlap in both $\delta^{15} \mathrm{~N}$ and $\delta^{13} \mathrm{C}$ signatures among species. The high interspecific overlap in $\delta^{15} \mathrm{~N}$ values was expected, given the similarities in the diet of the species from this community. However, several unexpected results, such as (1) the consistently higher $\delta^{15} \mathrm{~N}$ signatures of white terns (Gygis alba), (2) the large variation in inter-specific differences in $\delta^{15} \mathrm{~N}$ signatures among the sampling groups (season, age, island and tissue) and (3) the consistent low $\delta^{15} \mathrm{~N}$ values of breeding birds during the northwest monsoon (austral summer), suggest that $\delta^{15} \mathrm{~N}$ signatures cannot be used as indicators of seabird trophic levels in this community. The high interspecific overlap in $\delta^{13} \mathrm{C}$ signatures and the absence, during the breeding season, of a $\delta^{13} \mathrm{C}$ gradient that follows the inshore-offshore foraging gradient within the community can be explained by the habitat homogeneity of the Seychelles continental shelf and suggest that birds forage mostly within the limits of this "plateau". On the other hand, the similarities in $\delta^{13} \mathrm{C}$ values between the breeding and inter-breeding periods in species that are known to show post-breeding dispersal, strongly support the hypothesis of a lack of latitudinal variation in $\delta^{13} \mathrm{C}$ signatures of POM in the central Indian Ocean, and the consequent inaccuracy of $\delta^{13} \mathrm{C}$ values to track seabird movements within this geographic area. Inter-specific differences in mercury levels seem to be related to prey size, while consistent higher mercury concentrations in one of the studied islands suggest different island mercurybackgrounds and possible segregation in foraging areas between the seabirds of the two islands.

Keywords: stable isotopes; mercury; seabirds; foraging strategy 


\section{Introduction}

Seabird foraging ecology has been largely studied for most taxonomic groups and geographical areas around the world (Pearson 1968; Harrison et al. 1983; Croxall 1987; Spear et al. 2007). However, most studies are restricted to a few species within whole seabird communities and temporally constrained to the breeding period. During the last decades, the development of techniques to analyse stable isotopes and contaminant levels (e.g. mercury) in seabird tissues has provided a major contribution to fill in these gaps (Hobson and Clark 1992; Monteiro et al. 1995; Cherel et al. 2006). Stable isotope analysis (SIA), a technique based on the fact that ratios of stable isotopes in tissues of predators reflect those in their prey in a predictable manner, is recognised as a powerful tool to understand dietary patterns and trophic relationships of animal communities (Hobson and Clark 1992; Sydeman et al. 1997). Stable isotope measurements of carbon $\left(\delta^{13} \mathrm{C}\right)$ and nitrogen $\left(\delta^{15} \mathrm{~N}\right)$ are the most commonly used in marine ecosystems. Nitrogen-15 is enriched at each successive trophic level, whereas carbon-13 is enriched in inshore or benthic feeders relative to offshore or pelagic feeders (Shealer 2001). Furthermore, stable isotopes can be used to track the movement of seabirds across isotopic gradients, as individuals moving between isotopically distinct food webs can carry with them information on the location of their previous feeding areas (Nisbet et al. 2002; Forero and Hobson 2003).

Investigation of seabird exposure to contaminants such as mercury $(\mathrm{Hg})$ can also provide valuable information on foraging ecology (e.g. Thompson et al. 1998a, Monteiro et al. 1995, Bearhop et al. 2000a). Unlike other heavy metals present in the marine environment, once mercury has entered the food web it may suffer bioamplification through food chains (Bryan 1979, Eisler 1987). Hence, seabirds, as marine top-predators, usually exhibit high mercury levels in tissues, including feathers 
which are the major pathway for mercury elimination through moulting (Burger et al. 1993, Monteiro et al. 1995, Monteiro and Furness 2001). Seabirds feeding at higher trophic levels or relying mostly on mesopelagic prey exhibit higher mercury levels (Monteiro et al. 1998, Thompson et al. 1998a, Ochoa-acuña et al. 2002, Kojadinovic et al. 2007). Some seabird species foraging offshore and/or in more remote areas are less prone to have high mercury levels than seabirds foraging inshore and/or in more polluted areas (Burger et al. 2001, Nisbet et al. 2002), although this is not always the case (Ochoa-acuña et al. 2002).

Studies on stable isotopes and mercury levels for entire tropical seabird communities are inexistent and the role of such indicators in explaining seabird foraging ecology is virtually unknown (but see Kojadinovic et al. 2008). Among tropical seabirds there is a strong overlap in the diet of both inshore and offshore seabirds (Diamond 1983, Harrison et al. 1983, Surman and Wooller 2003, Catry et al. in revision). Diet segregation within these seabird communities is mainly based on prey size and foraging ranges, and less on prey species (Diamond 1983, Surman and Wooller 2003, Catry et al. in revision). This high overlap is presumably derived from the incapacity of tropical seabirds to dive more than a few meters. One of the most important foraging strategies of tropical seabirds is to feed at the surface within multispecies flocks, in association with shoals of predatory fishes which drive prey to the surface, making them available to the birds (Ballance and Pitman 1999, Jaquemet et al. 2004). The present study focused on the tropical seabird community of two neighboring islands (Aride and Cousin) of the Seychelles archipelago, western Indian Ocean. Recently, Catry et al. (in revision) analyzed the diet of this community during the breeding season and recorded a high overlap in the diet composition of most species, with the exception of the white-tailed tropicbird (Phaethon lepturus). In the present 
study we determined $\delta^{15} \mathrm{~N}$ and $\delta^{13} \mathrm{C}$ signatures and mercury levels in eight seabird species from this community (which include nine species). We investigated interspecific and intra-specific (age, season and island related) trophic segregation during both the breeding and inter-breeding periods and assessed the potential of stable isotopes and mercury levels to characterize foraging ecology of tropical seabirds.

The studied seabird community includes species that forage in a range gradient between inshore and offshore areas during the breeding season (from the more coastal to the more offshore foragers: lesser noddy Anous tenuirostris, bridled tern Sterna anaethetus white tern Gygis alba, brown noddy Anous stolidus, Audubon's shearwater Puffinus lherminieri, sooty tern Sterna fuscata, white-tailed tropicbird Phaethon lepturus and wedge-tailed shearwater Puffinus pacificus, respectively; Bailey 1968, Feare 1981, Diamond and Prŷs-Jones 1986, Schreiber and Burger 2001, pers.obs). For this reason, we would expect to find a similar gradient in $\delta^{13} \mathrm{C}$ signatures or, at least, significant differences among more inshore and more offshore foraging species during the breeding season.

Given the high overlap in diet composition recorded in this community (Catry in revision) we would expect similar $\delta^{15} \mathrm{~N}$ signatures and mercury levels among species and between islands during the breeding season (with the possible exception of whitetailed tropicbirds that show less overlap in diet). Larger seabird species consume larger prey (Catry et al. in revision) and could presumably present higher $\delta 15 \mathrm{~N}$ values.

The foraging ecology of these species during the inter-breeding period is poorly known. However, preliminary studies of the at-sea distribution of seabirds in the Indian Ocean suggest that species such as the wedge-tailed shearwater, the white tailed tropicbird and the sooty tern show post-breeding dispersal, whereas others such 
as the Audubon's shearwaters, the lesser noddy, the brown noddy and the white tern are probably tied to their breeding grounds all year round (Bailey 1968). Hence, we would expect differences in the $\delta^{13} \mathrm{C}$ signatures between the breeding and non breeding seasons of species that show post-breeding dispersal and overall unchanged signatures in more resident species.

\section{Material \& Methods}

\section{Study area}

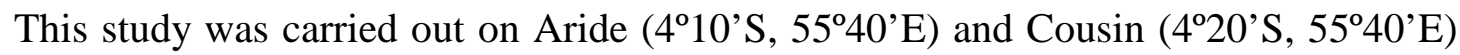
Islands, two neighbouring islands (situated $10 \mathrm{kms}$ apart) of the Seychelles archipelago, western Indian Ocean. The climate is seasonal, with hot and wet north westerly winds between November and March (northwest monsoon, hereafter NW monsoon), and dryer, less hot south-easterly winds between May and September (southeast monsoon, hereafter SE monsoon). White-tailed tropicbird, white tern and Audubon's shearwater breed all year round. Brown noddy and lesser noddy breed during the two monsoons, but predominantly during the SE monsoon. Wedge-tailed shearwater breeds almost exclusively during the NW monsoon. Bridled tern has a non-annual breeding cycle of 9 months. Sooty tern breeds exclusively on Aride Island during the SE monsoon.

\section{Sample collection}

On Aride Island, we collected body feathers of adults and chicks of Audubon's shearwaters, white-tailed tropicbirds, brown noddies, lesser noddies and white terns, both during the SE monsoon of 2005 and the NW monsoon of 2006. Sooty terns were sampled only during the SE monsoon and wedge-tailed shearwaters during the NW 
monsoon. On Cousin Island, adults from all the previous species (except the sooty tern) plus the bridled tern were sampled (feathers and blood) during the SE monsoon of 2005. Feather samples were pulled (between 7 and 10) from the body (breast) of breeding adults and chicks (during the linear growth phase) and stored in paper envelopes until analysed. Blood samples were drawn from adults via venepuncture of wing vein and conserved in $70 \%$ ethanol because the remoteness of the sampling sites did not leave the option of freezing them on site. This procedure does not significantly alter the isotopic composition of tissue (Hobson et al. 1997) and was also previously used to assess mercury concentrations in blood samples of seabirds (e.g. GonzálezSólis et al. 2002).

\section{Isotopic determination}

Breast feathers were washed vigorously in triple baths of $0.25 \mathrm{~N}$ sodium hydroxide solution alternated with triple baths of deionized water in order to remove adherent external contamination as well as external lipid layer resulting from preening. Feathers were then dried in an oven for $24 \mathrm{~h}$ at $50^{\circ} \mathrm{C}$ and cut into small fragments for isotopic analysis. Stable-carbon and nitrogen isotope assays of feather samples were carried out on $0.35 \pm 0.05 \mathrm{mg}$ sub-samples loaded into tin cups. Ethanol from blood samples was evaporated in an aspirating hood. Blood samples were dried at $40^{\circ} \mathrm{C}$ during $24 \mathrm{~h}$, then re-suspended in $500 \mu \mathrm{l}$ MilliQ quality water and sonicated for $1 \mathrm{~min}$ with a Sonimass S20, then frozen at $-80^{\circ} \mathrm{C}$ and finally freeze-dried during 3 days. Before the analysis procedure, samples were ground to fine powder and homogenised. Stable-carbon and nitrogen isotope assays of blood samples were carried out on 0.42 $\pm 0.05 \mathrm{mg}$ (range 0.35-0.50) sub-samples loaded into tin cups. Relative abundance of

stables isotopes of carbon $\left({ }^{13} \mathrm{C} /{ }^{12} \mathrm{C}\right)$ and nitrogen $\left({ }^{15} \mathrm{~N} /{ }^{14} \mathrm{~N}\right)$ were determined by 
continuous-flow isotope-ratio mass spectrometry (CF-IRMS). Analyses were conducted using a Euro EA 3024. Results are presented in the usual delta notation $(\delta)$ relative to the Pee Dee Belemnite (PDB) for $\delta^{13} \mathrm{C}$, and atmospheric nitrogen $\left(\mathrm{N}_{2}\right)$ for $\delta^{15} \mathrm{~N}$. Replicate measurements of internal laboratory standards indicate measurement errors of \pm 0.1 and $\pm 0.3 \%$ for $\delta^{13} \mathrm{C}$ and $\delta^{15} \mathrm{~N}$, respectively.

For mercury, at least two aliquots ranging from 5 to $20 \mathrm{mg}$ of dried blood and breast feather material were directly analysed in an Advanced Mercury Analyser spectrophotometer (Altec AMA 254). Mercury analyses were run with respect to a thorough quality control program including analyses of lobster hepatopancreas TORT-2 (certified value $0.27 \pm 0.06$ ) reference material purchased from the National Research Council, Canada. Standard samples were analyzed under the same conditions as the samples. The results were in good agreement with the certified values (average measured value was $0.27 \pm 0.02, n=10$ ), with an average recovery rate of $100 \%$. Detection limit was $8 \mathrm{ng} \cdot \mathrm{g}^{-1}$ dry wt. Mercury levels in feathers and blood samples are reported in $\mu \mathrm{g} \cdot \mathrm{g}^{-1} \mathrm{dry}$ wt throughout this paper.

\section{Statistical analysis}

A three-way analysis of variance (ANOVA), followed by Tuckey post-hoc tests, was used to segregate carbon and nitrogen isotopes by species (Audubon's shearwater, white-tailed tropicbird, brown noddy, lesser noddy and white tern), age (adult, chick) and season (SE and NW monsoons), within the seabird community of Aride Island. To compare mercury levels between species, age and season, controlling for the effect of trophic level and foraging areas, a general linear model (GLM) was run with mercury values as the dependent variable, species, age and season as factors, and $\delta^{15} \mathrm{~N}$ 
and $\delta^{13} \mathrm{C}$ as covariates. Both the three-way ANOVA and the GLM are robust analyses that tolerate moderate deviations from normality and homogeneity of variances.

In order to investigate intra-specific differences in $\delta^{15} \mathrm{~N}, \delta^{13} \mathrm{C}$ and mercury values in adult body feathers between birds sampled on Aride and Cousin Islands (during the SE monsoon) we performed one-way ANOVAs and, whenever the homogeneity of variances condition was not verified, we used Mann-Whitney U Tests. One-way ANOVAs were also used to assess differences in $\delta^{15} \mathrm{~N}, \delta^{13} \mathrm{C}$ and mercury values in blood of adult seabirds sampled on Cousin Island.

All data are presented as mean \pm standard deviation (SD). Results were considered significant at $\mathrm{P}<0.05$.

\section{Results}

$\underline{\text { Inter-specific comparisons }}$

Overall, we recorded a high overlap in $\delta^{15} \mathrm{~N}$ and $\delta^{13} \mathrm{C}$ signatures in body feathers of seabirds within the studied community (Figures 1 and 2).

Inter-specific differences in $\delta^{15} \mathrm{~N}$ signatures were not consistent among the sampling groups (season, age, island and tissue; Figure 3). Significant inter-specific differences in $\delta^{15} \mathrm{~N}$ signatures within seabirds of Aride Island were recorded only for white terns that showed higher $\delta^{15} \mathrm{~N}$ values than all the other species (Table 1, Figure 2). Regarding blood samples, differences in $\delta^{15} \mathrm{~N}$ measurements were significant for all species $\left(\mathrm{F}_{6,64}=10.70, \mathrm{P}<0.001\right)$ except for brown and lesser noddies, and brown noddies and bridled terns that showed similar values.

In contrast with $\delta^{15} \mathrm{~N}$, inter-specific differences in $\delta^{13} \mathrm{C}$ signatures among the sampling groups showed a general consistent pattern, with crescent $\delta^{13} \mathrm{C}$ values from lesser noddies, audubon's shearwaters, brown noddies and white terns, to white-tailed 
tropicbirds (Figure 4). Small but significant inter-specific differences in $\delta^{13} \mathrm{C}$ signatures were found among the seabirds of Aride Island (only Audubon's shearwaters and brown noddies had similar $\delta^{13} \mathrm{C}$ signatures; Table 1$) . \delta^{13} \mathrm{C}$ signatures of blood from adults of the seven species sampled on Cousin Island also showed significant inter-specific differences $\left(\mathrm{F}_{6,64}=10.80, \mathrm{P}<0.001\right)$ but only white-tailed tropicbirds and brown noddies, and white-tailed tropicbirds and bridled terns, with similar signatures, were different from the other species.

We recorded large inter-specific differences in mercury values among the sampling groups for most species, but overall, white-tailed tropicbirds showed the highest mercury levels within the community, both on Aride and Cousin Islands (Figure 5).

\section{$\underline{\text { Between-age and season comparisons }}$}

The factorial ANOVA performed for the seabirds of Aride Island showed that $\delta^{15} \mathrm{~N}$ signatures were presumably not influenced by age and season (Table 1). However, the interaction between age and season was significant: overall, chicks grown during the SE monsoon showed significantly higher $\delta^{15} \mathrm{~N}$ values than chicks grown during the NW monsoon and than adults sampled in the SE monsoon (Table 1).

$\delta^{13} \mathrm{C}$ signatures of all sampled seabirds from Aride Island were segregated by season (Table 3). Overall, individuals sampled in the NW monsoon exhibited lower (more depleted) $\delta^{13} \mathrm{C}$ signatures. Age, per se, did not seem to affect $\delta^{13} \mathrm{C}$ values (Table 1).

The GLM analysis showed that mercury levels in body feathers of seabirds of Aride Island were significantly but weakly correlated with $\delta^{15} \mathrm{~N}$ (Table 1). Both age and season had a significant effect on mercury levels: individuals sampled during the NW monsoon, irrespective of age, showed higher mercury values, and chicks, irrespective of season, showed lower mercury values (Table 1). 


\section{$\underline{\text { Between-island comparisons }}$}

We found a high overlap in $\delta^{15} \mathrm{~N}$ and $\delta^{13} \mathrm{C}$ signatures of adult body feathers between birds sampled on Aride and Cousin Islands (Figure 1). However, lesser noddies from Aride Island had significantly lower $\delta^{15} \mathrm{~N}$ values than birds from Cousin Island and white-tailed tropicbirds from Aride Island had significantly higher (more enriched) $\delta^{13} \mathrm{C}$ values than tropicbirds from Cousin Island (Table 2).

For all species except white terns, mercury levels were significantly higher in seabirds from Aride Island than in those from Cousin Island (Table 2, Figure 6).

\section{Discussion}

Most seabirds undergo their moult cycle during the inter-breeding season, probably as a way to avoid overlapping the energetic cost of breeding and that of moulting (Hamer et al. 2001). The moult cycle of most species focused in this study is poorly known, but previous studies on Ascension Island, Atlantic Ocean, suggest that white terns, sooty terns and lesser noddies start moulting after breeding, with the moult of body feathers taking place during several months of the inter-breeding period (Dorward 1963, Ashmole 1963a, 1963b). Thus, the isotopic signatures of the body feathers of adults are, presumably, indicators of the foraging areas and trophic level during the inter-breeding period, whereas the isotopic signatures of the feathers of chicks and the blood of adults provide the same kind of information for the breeding season. Mercury levels in feathers result from a gradual elimination, during the period of feather growth, of a body pool of mercury previously accumulated in internal tissues (Monteiro and Furness 2001) and may, therefore, reflect mercury intake during an extended period (Bearhop et al. 2000a). Hence, the isotope values and mercury concentrations in adult body feathers are effectively "uncoupled". Once seabirds 
attend breeding colonies for large periods of time, mercury levels in adult body feathers may reflect breeding season diet to some extent (Thompson et al. 1998a, Bearhop et al. 2000a).

\section{$\underline{\text { Inter-specific comparisons }}$}

Unlike several studies conducted in temperate and polar areas (e.g. Hobson et al. 1994, 2002, Thompson et al. 1999, Cherel et al. 2006), we recorded a high interspecific overlap in the $\delta^{15} \mathrm{~N}$ and $\delta^{13} \mathrm{C}$ signatures of the seabird community of Aride and Cousin Islands.

The narrow range in $\delta^{15} \mathrm{~N}$ values among species (all within sampling groups differences $<2 \%$ ) was an expected result taking into account the high overlap in diet composition recorded for this community (Catry et al. in revision). Previous studies of different tropical seabird communities have shown that, despite having a diverse diet, most tropical seabirds rely mainly upon a few pelagic fish (mainly juveniles) and squid families (Diamond 1983, Harrison et al. 1983, Surman and Wooller 2003, Spear et al. 2007, Catry et al. in revision). Temperate and polar seabird communities can show less diverse diets than those from tropical areas, however, the presence of specialized species relying upon plankton or crustaceans, as well as upon fish or squid, can explain the higher segregation in $\delta^{15} \mathrm{~N}$ signatures among those communities (Sydeman et al. 1997, Thompson et al. 1999, Hobson et al. 2002, Cherel et al. 2006). Despite the expected high overlap in $\delta^{15} \mathrm{~N}$ signatures recorded in this study, there were two unexpected results: (1) the absence of differences in $\delta^{15} \mathrm{~N}$ values of feathers of white-tailed tropicbird chicks in comparison to other species and (2) the generally higher $\delta^{15} \mathrm{~N}$ values of body feathers of white tern chicks. White-tailed tropicbird chicks have the lowest overlap in diet composition with the other species, due to an 
almost absence of Mullidae (the main prey for most of the other seabird species) and a higher consumption of squid (Catry et al. in revision), which seems to be $\delta^{15} \mathrm{~N}$ enriched (Jaquemet et al. in revision). On the other hand, white-tailed tropicbird chicks also consume the larger prey within the whole community (Catry et al. in revision), and prey size is often positively correlated with $\delta^{15} \mathrm{~N}$ signatures (Ménard et al. 2007). Accordingly, we would expect white-tailed tropicbird chicks to show the highest $\delta^{15} \mathrm{~N}$ values. However, and surprisingly, white terns exhibited the highest $\delta^{15} \mathrm{~N}$ signatures in body feathers of chicks, suggesting that they forage at a higher trophic level, which does not appear to be true, at least for the breeding season, given the diet composition described (Catry et al. in revision). Moreover, white tern chicks are fed with smaller prey than most of the other species (Catry et al. in revision), so the higher $\delta^{15} \mathrm{~N}$ values cannot be related to prey size either. These results suggest that $\delta^{15} \mathrm{~N}$ signatures are poor indicators of trophic level for the seabirds of this community. Furthermore, inter-specific differences in $\delta^{15} \mathrm{~N}$ signatures were not consistent among the sampling groups (season, age, island and tissue), supporting the fact that $\delta^{15} \mathrm{~N}$ values can hardly be used to characterize trophic relationships within the studied community and that specific nitrogen excretion rates do not play an important role in explaining inter-specific differences. Kojadinovic et al. (2008) recorded significant differences in $\delta^{15} \mathrm{~N}$ signatures between Audubon's shearwaters and white-tailed tropicbirds breeding in the southwest Indian Ocean and suggest that this could be due mainly to differences in prey size taken by the two species. However, they did not study the diet of these species and, therefore, could not attribute such differences to diet composition. Ménard et al. (2007), studying the foraging ecology of two migratory fish predators of the western Indian Ocean, found inter-specific differences in $\delta^{15} \mathrm{~N}$ signatures of yellowfin tunas and swordfish, suggesting different feeding 
strategies and trophic levels between the two species. Interestingly, these differences were smaller in the north of the sampling area $\left(5^{\circ} \mathrm{N}\right.$, nearer to the Seychelles archipelago $)$ and higher in the south $\left(25^{\circ} \mathrm{S}\right)$. Given that there is no evidence that such predators have different feeding habits within their distribution ranges, this fact suggests that there may be a latitudinal effect in the baseline values of $\delta^{15} \mathrm{~N}$ and an inaccuracy in using $\delta^{15} \mathrm{~N}$ signatures to explain trophic levels.

Despite the multiple significant differences recorded, we found a high overlap in carbon isotopic signatures among species (all differences within sampling groups $<2$ $\%$ ). For seabird species, $\delta^{13} \mathrm{C}$ signatures usually provide information on foraging habitats, with lower (more depleted) values related to offshore or pelagic foraging and higher (more enriched) values correspondent to inshore or benthic foraging (e.g. Thompson et al. 2000, Hobson et al. 2002). In this study, inter-specific differences in $\delta^{13} \mathrm{C}$ signatures for the breeding season (chick feathers) were not related to foraging range as expected. In fact, the white-tailed tropicbird and the sooty tern, two of the most offshore species, had the highest $\delta^{13} \mathrm{C}$ signatures, whereas the lesser noddy, a predominantly inshore forager, had the lowest $\delta^{13} \mathrm{C}$ values within the whole community. It therefore appears that $\delta^{13} \mathrm{C}$ values of seabirds from Aride and Cousin Islands cannot be used as an indicator of inshore versus offshore foraging preference during the breeding season. Sherwood and Rose (2005), studying the isotopic signatures of invertebrate and fish in the Newfoundland and Labrador continental shelf, also found an absence of inshore-offshore gradient in $\delta^{13} \mathrm{C}$ signatures. The central islands of the Seychelles archipelago are also situated on a continental shelf the Seychelles Bank - where depths of 44-65m extend for about $43000 \mathrm{~km}^{2}$ (Braithwaite 1984). Although some preliminary results on incubation shift duration suggest that sooty terns, white-tailed tropicbirds and wedge-tailed shearwaters forage 
further offshore than other species during the incubation period (Le Corre et al. unpublished), the high overlap in diet composition within the community (Catry et al. in revision) suggest that most species forage mainly within the limits of the Seychelles Bank. Inter-specific differences found in $\delta^{13} \mathrm{C}$ signatures may reflect differences in foraging areas, but proximity to the breeding colony does not appear to be the factor that most influenced $\delta^{13} \mathrm{C}$ values in this seabird community. This segregation may be related to avoidance of inter-specific competition, which is most important during the breeding season, when adults try to feed their chicks with high-energetic prey items (Massias and Becker 1990, Paiva et al. 2006). Indeed, $\delta^{13} \mathrm{C}$ signatures from blood of adults from Cousin Island show higher similarity among species than $\delta^{13} \mathrm{C}$ values from body feathers of chicks. This suggests that adults, when foraging for themselves, are probably more opportunistic than when feeding for their chicks, leading to lower competition. It is possible that $\delta^{13} \mathrm{C}$ signatures may be good indicators of inshore offshore foraging areas for these species during the inter-breeding period. In fact, a previous study in the western Indian Ocean that compared $\delta^{13} \mathrm{C}$ signatures between lesser noddies and roseate terns suggested that lesser noddies may be largely oceanic during the inter-breeding period, whereas roseate terns may be more coastal period (Monticelli et al. in press).

Apart from the inshore-offshore variation, $\delta^{13} \mathrm{C}$ values of particulate organic matter (POM), and thereafter of the entire food chain, may show a latitudinal variation (Cherel et al. 2000, 2007). For example, in the southern Indian Ocean, enriched $\delta^{13} \mathrm{C}$ POM values occur north of $40^{\circ} \mathrm{S}$ and depleted $\delta^{13} \mathrm{C}-\mathrm{POM}$ values occur south of $45^{\circ} \mathrm{S}$ (François et al. 1993). The similarities in $\delta^{13} \mathrm{C}$ signatures between adults and chicks for each season on Aride Island suggest that, whatever the species and the breeding season, adult birds spend the non-breeding period not far from their breeding grounds, 
which was a unexpected result. In fact, preliminary studies of the at-sea distribution of seabirds in the Indian Ocean suggest that species such as the wedge-tailed shearwater, the white-tailed tropicbird and the sooty tern show post-breeding dispersal (Bailey 1968). These contradictory results strongly support the hypothesis of a lack of latitudinal variation in $\delta^{13} \mathrm{C}$ values of POM in the "central" western Indian Ocean and the consequent inaccuracy of $\delta^{13} \mathrm{C}$ signatures to track seabird movements in this region. Consistently, $\delta^{13} \mathrm{C}$ values in the muscle tissues of yellowfin tuna and swordfish sampled in the western Indian Ocean varied weakly along a latitudinal gradient of about $30^{\circ}\left(23^{\circ} \mathrm{S}\right.$ to $5^{\circ} \mathrm{N}$; Ménard et al. 2007).

With few exceptions, we found three main groups based on mercury levels: one group with the highest mercury values that includes the white-tailed tropicbirds, another with intermediate mercury values that includes wedge-tailed shearwaters, brown noddies, sooty terns and white terns, and the last group, with the lowest mercury levels, that includes Audubon's shearwaters, lesser noddies and bridled terns. Assuming that mercury levels in adult body feathers partly reflect breeding season diet (see above), and given the high similarities in the diet of this community (Catry et al. in revision), inter-specific differences in mercury levels can hardly be explain by diet composition. Previous studies have found a direct relationship between size and mercury levels in fish (e.g. Arcos et al. 2002, Kojadinovic et al. 2006). This could partly explain the differences found in this study, because mercury levels seem to be positively correlated with prey size (Catry et al. in revision). However, differences in mercury levels between species can also be related to physiological differences among seabird taxa with some species being more effective in eliminating mercury than others (Monteiro et al. 1995, Becker et al. 2002), or even to differences in metabolic rates. 


\section{$\underline{\text { Between-age and season comparisons }}$}

$\delta^{15} \mathrm{~N}$ signatures of seabirds from Aride Island were not segregated by age or season. There was, however, an interaction between age and season, and chicks reared during the SE monsoon showed significantly higher $\delta^{15} \mathrm{~N}$ values than chicks reared during the NW monsoon. Surprisingly, Ménard et al (2007) found the opposite seasonal effect for predatory fishes sampled in the western Indian Ocean. The diet of white tern and white-tailed tropicbird chicks on Aride and Cousin Islands showed no significant differences in prey composition between the SE and NW monsoons (Catry et al. in revision) suggesting once more that those variations in $\delta^{15} \mathrm{~N}$ values may be related to environmental factors rather than to trophic level. Seabirds sampled in the NW monsoon exhibited lower $\delta^{13} \mathrm{C}$ signatures than birds sampled in the SE monsoon, irrespective of age class. Because during the breeding season adults are constrained to foraging relatively close to their colonies, the consistent differences found in $\delta^{13} \mathrm{C}$ values between chicks reared during the two distinct monsoons can reflect slight differences in foraging areas but not large movements to somewhat distant areas. The fact that the same pattern is exhibited between adults sampled in the two monsoons, suggests that these differences may be related to temporal changes in background $\delta^{13} \mathrm{C}$ values, instead of being related to differences in seabird foraging areas. Monticelli et al. (in press) also found small annual differences in $\delta^{13} \mathrm{C}$ signatures for adult lesser noddies breeding in the SE season on Aride Island, which agrees with this hypothesis. As recorded in several other studies (e.g. Monteiro et al. 1995, Bearhop et al. 2000b, Kojadinovic et al. 2007), body feathers of adult seabirds from Aride Island had significantly higher mercury values than body feathers of chicks, probably as a consequence of large periods of exposure by adults and thus high levels of mercury 
accumulation. More unexpected was the consistent record of higher mercury values in body feathers of birds sampled during the NW monsoon (for all species except whitetailed tropicbirds). White tern and white-tailed tropicbirds chicks show similar diets between the NW and SE monsoons with no evidence of chicks consuming larger prey during the NW monsoon (Catry et al. in revision). Therefore, other factors, such as annual or seasonal variations in the background levels of mercury in this part of the Indian Ocean, should be involved in explaining the observed differences.

\section{$\underline{\text { Between-island comparisons }}$}

Overall, body feathers of adults of the five species sampled on Aride and Cousin Islands during the SE monsoon showed no intra-specific differences in $\delta^{15} \mathrm{~N}$ and $\delta^{13} \mathrm{C}$ signatures between islands. The exceptions were small differences found in the $\delta^{15} \mathrm{~N}$ and $\delta^{13} \mathrm{C}$ values of lesser noddies and white-tailed tropicbirds, respectively. However, and despite the homogeneity in $\delta^{15} \mathrm{~N}$ and $\delta^{13} \mathrm{C}$ signatures between islands, we recorded significantly higher mercury values for all seabird species (except for white tern) on Aride Island than on Cousin Island. The consistently higher mercury levels in adult birds from Aride Island apparently suggest that seabirds from Aride and Cousin Islands exhibit different diets and/or forage on different areas. Small differences in diet, even if not correlated with trophic level, can lead to significant differences in mercury levels in bird tissues. Thompson et al. (1998b) found out that differences in mercury levels in northern fulmars between two neighbouring islands in the Shetland were due to the consumption of two mesopelagic prey species (with higher mercury levels) in only one of the colonies. However, at least during the breeding season small differences found in the diet of birds from Aride and Cousin Islands resulted mainly from differences in the proportions of each prey type, rather than from a difference in 
prey species taken in each island (Catry et al. in revision). Again in the Shetland archipelago, Thompson et al. (1992) and Bearhop et al. (2000b) found consistently higher mercury levels in the seabird community from one of two neighbouring islands. They argued that the difference in mercury levels between the two colonies could be a product of differences in the background levels in the two islands. Likewise, different background mercury levels between the foraging areas of birds from Aride and Cousin Islands may also determine differences in mercury levels in body feathers of seabirds between the two islands. This explanation is partly supported by the mercury levels found in feathers of chicks from Aride Island, that were lower than those of adults from the same colony (except for white terns) but higher, at least for Audubon's shearwater, lesser noddies and brown noddies, than those of adults from Cousin Island. Non-overlap in foraging areas by seabirds of neighbouring islands as a method to avoid competition for food has already been recorded by several authors, especially when large colonies are involved (Ainley et al. 2004, V. Paiva, pers.comm.). However, to our knowledge, such an apparent segregation in foraging areas at such a small geographic scale has never previously been reported. Although different background mercury levels between foraging areas seems to be the most plausible hypothesis to explain different mercury concentrations in body feathers of adult seabirds from Aride and Cousin Islands, we cannot exclude the hypothesis that these may be the result of segregation in foraging areas during the inter-breeding period.

\section{Conclusion}

To our knowledge, this is the first study focusing on the role of stable isotopes and mercury concentrations to describe foraging ecology in a large and diverse tropical 
seabird community. Contrarily to studies conducted in temperate and polar areas, several unexpected and contradictory results revealed that $\delta^{15} \mathrm{~N}$ signatures cannot be used as indicators of seabird trophic level within the studied community. $\delta^{13} \mathrm{C}$ signatures failed to describe inshore-offshore patterns of seabird foraging during the breeding season, which may be due to the habitat homogeneity of the Seychelles continental shelf. Furthermore, our results strongly support the hypothesis of a lack of latitudinal variation in $\delta^{13} \mathrm{C}$ signatures of POM in the central Indian Ocean and the consequent inaccuracy of $\delta^{13} \mathrm{C}$ values to track seabird movements within this geographic area. Results on mercury concentrations suggest different island mercury backgrounds and possible segregation in foraging areas between the seabirds of the two islands.

Further studies investigating different tropical seabird communities will be important to clarify whether the inaccuracy of stable isotopes to characterize seabird foraging ecology is a general rule for tropical marine ecosystems.

\section{Acknowledgements}

We would like to acknowledge Island Conservation Society (ICS) and Nature Seychelles for permission to work on Aride and Cousin Islands, respectively. TC was funded by a portuguese doctoral grant from Fundação para a Ciência e Tecnologia (SFRH/BD/16706/2004). This work is part of a regional programme on seabirds as bioindicators of the marine environment, funded by the Western Indian Ocean Marine Science Association (Marine Science for Management Grant, MASMA/AG/2004/04), and by the Agence National pour la Recherche (Program REMIGE - ANR Biodiversité 2005-011). This research was conducted under permission of the Seychelles Bureau of Standards, Republic of Seychelles. 


\section{References}

Ainley, D.G., Ribic, C.A., Ballard, G., Heath, S., Gaffney, I., Karl, B.J., Barton, K.J., Wilson, P.R. \& Webb, S. 2004. Geographic structure of Adélie Penguin populations: overlap in colony-specific foraging areas. Ecological Monographs 74 (1): 159-178.

Arcos, J.M., Ruiz, X., Bearhop, S. \& Furness, R.W. 2002. Mercury levels in seabirds and their fish prey at the Ebro Delta (NW Mediterranean): the role of trawler discards as a source of contamination. Marine Ecology Progress Series 232: 281-290.

Bailey, R.S. 1968. The pelagic distribution of sea-birds in the western Indian Ocean. Ibis 110: 493-519.

Ballance, L.T. \& Pitman, R.L. 1999. Foraging ecology of tropical seabirds. In: Adams, N.J. \& Slotow, R.H. (eds) Proc. 22 Int. Ornithol. Congr., Durban: 2057-2071. Johannesburg: BirdLife South Africa.

Bearhop, S., Phillips, R.A., Thompson, D.R., Waldron, S. \& Furness, R.W. 2000a. Variability in mercury concentrations of great skuas Catharacta skua: the influence of colony, diet and trophic status inferred from stable isotope signatures. Marine Ecology Progress Series 195: 261-268.

Bearhop, S., Waldron, S., Thompson, D.R. \& Furness, R.W. 2000b. Bioamplification of mercury in Great Skua Catharacta skua chicks: the influence of trophic status as determined by stable isotope signatures of blood and feathers. Marine Pollution Bulletin 40 (2): 181-185.

Becker, P.H., González-Solís, J., Behrends, B. \& Croxall, J. 2002. Feather mercury levels in seabirds at South Georgia: influence of trophic position, sex and age. Marine Ecology Progress Series 243: 261-269.

Braithwaite C.J.R. 1984. Geology of the Seychelles. In Stoddart, D.R. (Ed.) Biogeography and ecology of the Seychelles islands. Junk, The Hague.

Bryan, G.W. 1979. Bioaccumulation of marine pollutants. Philos. Trans. R. Soc. Lond. B. Biol. Sci. 286:483-505.

Burger, J., Shukla, T., Dixon, C., Shukla, S., McMahon, M.J., Ramos, R. Gochfeld, M. 2001. Metals in feathers of Sooty Tern, White Tern, Gray-backed Tern and Brown Noddy from islands in the North Pacific. Environmental Monitoring and Assessment 71: 71-89.

Burger, J., Schreiber, E.A.E, Gochfeld, M. 1993. Metal in avian feathers: bioindicators of environmental pollution. Rev. Environ. Toxicol. 5:203-311. 
Catry, T., Ramos, J.A., Jaquemet, S., Faulquier, L., Berlincourt, M., Hauselmann, A., Pinet, P. \& Le Corre, M. Submitted to which journal ???. Comparative foraging ecology of a tropical seabird community of Seychelles, western Indian Ocean.

Croxall, J.P. 1987. Seabirds: feeding ecology and role in marine ecosystems. Cambridge University Press. Cambridge.

Cherel, Y., Hobson, K.A. \& Weimerskirch, H. 2000. Using stable-isotope analysis of feathers to distinguish moulting and breeding origins of seabirds. Oecologia 122: 155162.

Cherel, Y., Phillips, R.A., Hobson, K.A. \& McGill, R. 2006. Stable isotope evidence of diverse species-specific and individual wintering strategies in seabirds. Biol. Lett. 2: 301-303.

Cherel, Y. \& Hobson, K.A. 2007. Geographical variation in carbon isotope signatures of marine predators: a tool to investigate their foraging areas in the Southern Ocean. Marine Ecology Progress Series 329: 281-287.

Diamond, A.W. 1983. Feeding overlap in some tropical and temperate seabird communities. Stud. Avian Biol. 8: 24-46.

Diamond A, Prŷs-Jones RP (1986) The biology of terns nesting at Aldabra Atoll, Indian Ocean, with particular reference to breeding seasonality. J Zool Lond 210: 527-549

Eisler, R. 1987. Mercury hazards to fish, wildlife and invertebrates: a synoptic review. Bio. Rev. 85: 1-10.

Feare, C.J. 1981. Breeding schedules and feeding strategies of Seychelles seabirds. Ostrich 32: 179-185.

Forero, M.G. \& Hobson, K.A. 2003. Using stable isotopes of nitrogen and carbon to study seabird ecology: applications in the Mediterranean seabird community. Scientia Marina 67 (Suppl.2):23-32.

François, R., Altabet, M.A., Goericke, R., McCorkle, D.C., Brunet, C. \& Poisson, A. 1993. Changes in the $\delta^{13} \mathrm{C}$ of surface water particulate organic matter across the subtropical convergence in the SW Indian Ocean. Global Biogeochemical Cycles 7: 627-644.

Harrison, C.S., Hida, T.S. \& Seki, M.P. 1983. Hawaiian seabird feeding ecology. Widlife Monographs 85: 1-71.

Hobson, K.A. \& Clark, R.G. 1992. Assessing avian diets using stable isotopes II: factors influencing diet-tissue fractionation. The Condor 94: 189-197 
Hobson, K.A., Piatt, J.F. \& Pitocchelli, J. 1994. Using stable isotopes to determine seabird trophic relationships. Journal of Animal Ecology 63: 786-798.

Hobson, K.A., Gilchrist, G. \& Falk, K. 2002. Isotopic investigations of seabirds of the North Water Polynya: contrasting trophic relationships between the eastern and western sectors. The Condor 104: 1-11.

Jaquemet S, Le Corre M, Weimerskirch H (2004) Seabird community structure in a coastal tropical environment: importance of associations with sub-surface predators and of Fish Aggregating Devices (FADs). Mar Ecol Prog Ser 268: 281-292

Jaquemet, S., Potier, M., Cherel, Y., Kojadinovic, J., Bustamante, P., Richard, P., Catry, T. \& Ramos, J.A. In Revision Diet and ecological niche of the sooty tern Sterna fuscata in the southwest Indian Ocean. Mar Biol

Kojadinovic J, Potier M, Le Corre M, Cosson RP, Bustamante P (2006) Mercury content in commercial pelagic fish and its risk assessment in the Western Indian Ocean. The Science of the Total Environment, 366: 688-700.

Kojadinovic, J., Le Corre, M., Cosson, R.P. \& Bustamante, P. 2007. Trace elements in three marine birds breeding on Reunion Island (Western Indian Ocean). Part 1: Factors influencing their bioaccumulation. Arch. Environ. Contam. Toxicol. 52: 418430.

Kojadinovic, J., Ménard, F., Bustamante, P., Cosson, R.P. \& Le Corre, M. In press. Trophic ecology of marine birds and pelagic fishes from Reunion Island as determined through stable isotope analysis. Marine Ecology Progress Series. Doi: 10.3354/meps 07355 .

Massias, A. \& Becker, P.H. 1990. Nutritive value of food and growth in Common Tern Sterna hirundo chicks. Ornis Scandinavica 21:187-194

Ménard, F., Lorrain, A., Potier, M. \& Marsac, F. 2007. Isotopic evidence of distinct feeding ecologies and movement patterns in two migratory predators (yellowfin tuna and swordfish) of the western Indian Ocean. Marine Biology 153: 141-152.

Monteiro, L.R., Furness, R.W. \& Del Nevo, A.J. 1995. Mercury levels in seabirds from the Azores, Mid-North Atlantic Ocean. Arch. Environ. Contam. Toxicol. 28: 304-309. 
Monteiro, L.R., Granadeiro, J.P. \& Furness, R.W. 1998. Relationship between mercury levels and diet in Azores seabirds. Marine Ecology Progress Series 166: 259265.

Monteiro, L.R. \& Furness, R.W. 2001. Kinetics, dose-response, excretion and toxicity of methylmercury in free-living Cory's Shearwater chicks. Environmental Toxicology and Chemistry 20 (8): 1816-1823.

Monticelli D, Ramos JA, Tavares PC, Bataille B, Lepoint G, Devillers P In Press Diet and foraging ecology of Roseate Terns and Lesser Noddies breeding sympatrically on Aride Island, Seychelles. Waterbirds

Nisbet, I.C.T., Montoya, J.P., Burger, J. \& Hatch, J.J. 2002. Use of stable isotopes to investigate individual differences in diets and mercury exposures among Common Terns Sterna hirundo in breeding and wintering grounds. Marine Ecology Progress Series. 242: 267-274.

Ochoa-acuña, H., Sepúlveda, M.S. \& Gross, T.S. 2002. Mercury in feathers from Chilean birds: influence of location, feeding strategy and taxonomic affiliation. Marine Pollution Bulletin 44:340-349.

Paiva, V.H., Ramos, J.A., Catry, T., Pedro, P., Medeiros, R. \& Palma, J. 2006. Influence of environmental factors and energetic value of food on Little Tern Sterna albifrons chick growth and food delivery. Bird Study 53: 1-11.

Pearson TH (1968) The feeding biology of seabird species breeding on the Farne Islands, Northumberland. J Anim Ecol 37: 521 -522

Schreiber, E.A. \& Burger, J. (Eds.) 2001. Biology of Marine Birds. CRC Press, Boca Raton, Florida.

Shealer, D. 2001. Foraging behavior and food of seabirds. In Schreiber, E.A. \& Burger, J. (Eds.) Biology of Marine Birds. CRC Press, Boca Raton, Florida.

Sherwood, G.D. \& Rose, G.A. 2005. Stable isotope analysis of some representative fish and invertebrates of the Newfoundland and Labrador continental shelf food web. Estuarine, Coastal and Shelf Science 63: 537-549.

Spear LB, Ainley DG, Walker WA (2007) Foraging dynamics of seabirds in the eastern tropical Pacific Ocean. Stud Avian Biol No. 35

SPSS 2004. SPSS user's guide. Version 12.0. SPSS, Inc., Chicago.

STATSOFT 2000. Statistica for Windows (computer program manual). StatSoft, Inc., Tulsa, OK. 
Surman, C.A. \& Wooller, R.D. 2003. Comparative foraging ecology of five sympatric terns at a sub-tropical island in the eastern Indian Ocean. J. Zool. London 259: 219230.

Sydeman, W.J., Hobson, K.A., Pyle, P. \& McLaren, E.B. 1997. Trophic relationships among seabirds in central California: combined stable isotope and conventional dietary approach. The Condor 99: 327-336.

Thompson, D.R., Furness, R.W. \& Barrett, R.T. 1992. Mercury concentrations in seabirds from colonies in the north-est Atlantic. Archives of Environmental and Contamination and Toxicology 23: 383-389.

Thompson, D.R., Bearhop, S., Speakman, J.R. \& Furness, R.W. 1998a. Feathers as a means of monitoring mercury in seabirds: insights from stable isotope analysis. Environmental Pollution 101: 193-200.

Thompson, D.R., Furness, R.W. \& Monteiro, L.R. 1998b. Seabirds as biomonitors of mercury inputs to epipelagic and mesopelagic marine food chains. The science of the Total Environment 213: 299-305.

Thompson, D.R., Lilliendahl, K., Solmundsson, J., Furness, R.W., Waldron, S. \& Phillips, R.A. 1999. Trophic relationships among six species of Icelandic seabirds as determined through stable isotope analysis. The Condor 101: 898-903.

Thompson, D.R., Phillips, R.A., Stewart, F.M. \& Waldron, S. 2000. Low $\delta^{13}$ C signatures in pelagic seabirds: lipid ingestion as a potential source of $\delta^{13} \mathrm{C}$-depleted carbon in the Procellariiformes. Marine Ecology Progress Series 208: 265-271.

Weimerskirch H (2007) Are seabirds foraging for unpredictable resources? Deep-Sea Res II 54: 211-223 
Table 1. Effect of species (Audubon's shearwater - AS, white-tailed tropicbird - WTT, brown noddy - BN, lesser noddy - LN and white tern WT), age (adults and chicks) and season (southeast and northwest monsoons), together with first order interaction terms, on $\delta^{13} \mathrm{C}$ and $\delta^{15} \mathrm{~N}$ (factorial ANOVA) and mercury values (GLM) in body feathers collected on Aride Island, Seychelles.

\begin{tabular}{|c|c|c|c|c|c|c|c|c|c|}
\hline \multirow[t]{2}{*}{ Variable } & \multicolumn{3}{|c|}{$\delta^{15} \mathrm{~N}$} & \multicolumn{3}{|c|}{$\delta^{13} \mathrm{C}$} & \multicolumn{3}{|c|}{$\mathrm{Hg}$} \\
\hline & $\mathrm{F}$ & $\mathrm{P}$ & Effect & $\mathrm{F}$ & $\mathrm{P}$ & Effect & $\mathrm{F}$ & $\mathrm{P}$ & Effect \\
\hline Species & $\mathrm{F}_{4,183}=14.7$ & 0.000 & WT > other species & $\mathrm{F}_{4,183}=75.9$ & 0.000 & $\begin{array}{c}\text { All different except } \\
\mathrm{BN}=\mathrm{AS}\end{array}$ & $\mathrm{F}_{4,183}=28.23$ & 0.000 & $\begin{array}{c}\text { WTT }>\text { other species } \\
\text { WT }>\text { LN, AS } \\
\text { BN }>\text { AS }\end{array}$ \\
\hline Age & $\mathrm{F}_{1,183}=0.9$ & 0.353 & --- & $\mathrm{F}_{1,183}=0.1$ & 0.722 & --- & $\mathrm{F}_{1,183}=404.37$ & 0.000 & adults $>$ chicks \\
\hline Season & $F_{1,183}=4.7$ & 0.031 & none detected & $F_{1,183}=57.4$ & 0.000 & $\mathrm{NW}<\mathrm{SE}$ & $F_{1,183}=107.42$ & 0.000 & $\mathrm{NW}>\mathrm{SE}$ \\
\hline Species*Age & $\mathrm{F}_{4,183}=2.1$ & 0.081 & --- & $\mathrm{F}_{4,183}=3.5$ & 0.010 & WTT: adult > chick & $F_{4,183}=12.24$ & 0.000 & $\begin{array}{c}\text { All species: adults > } \\
\text { chicks }\end{array}$ \\
\hline Species*Season & $\mathrm{F}_{4,183}=2.5$ & 0.045 & none detected & $\mathrm{F}_{4,183}=1.9$ & 0.109 & --- & $\mathrm{F}_{4,183}=8.38$ & 0.000 & $\begin{array}{l}\text { All species except } \\
\text { WTT: NW > SE }\end{array}$ \\
\hline Age*Season & $F_{1,183}=16.4$ & 0.000 & $\begin{array}{l}\text { chicks } S E>\text { adults } S E \\
\text { chicks } S E>\text { chicks NW }\end{array}$ & $F_{1,183}=0.8$ & 0.360 & --- & $F_{1,183}=15.73$ & 0.000 & $\begin{array}{c}\text { adults } \mathrm{NW}>\text { adults } \\
\mathrm{SE}>\text { chicks NW }> \\
\text { chicks SE }\end{array}$ \\
\hline Species*Age*Season & $\mathrm{F}_{4,183}=1.2$ & 0.325 & --- & $\mathrm{F}_{4,183}=1.0$ & 0.423 & --- & $\mathrm{F}_{4,183}=8.02$ & 0.000 & \\
\hline$\delta^{13} \mathrm{C}$ & --- & --- & --- & --- & --- & --- & $\mathrm{F}_{1,183}=2.48$ & 0.117 & --- \\
\hline$\delta^{15} \mathrm{~N}$ & --- & --- & --- & --- & --- & --- & $\mathrm{F}_{1,183}=4.93$ & 0.028 & \\
\hline
\end{tabular}


Table 2. Between-island comparisons in $\delta^{13} \mathrm{C}, \delta^{15} \mathrm{~N}$ and mercury values in adult body feathers of Audubon's shearwater, white-tailed tropicbird, brown noddy, lesser noddy and white tern collected during the southeast monsoon of 2005 on Aride Island, Seychelles. Statistical tests include one-way ANOVAs and, whenever the homogeneity of variances assumption was not verified, Mann-Whitney U Tests.

\begin{tabular}{|c|c|c|c|c|c|c|c|c|c|}
\hline & \multicolumn{3}{|c|}{$\delta^{15} \mathrm{~N}$} & \multicolumn{3}{|c|}{$\delta^{13} \mathrm{C}$} & \multicolumn{3}{|c|}{$\mathrm{Hg}$} \\
\hline & Test & $\mathrm{P}$ & Effect & Test & $\mathrm{P}$ & Effect & Test & $\mathrm{P}$ & Effect \\
\hline White-tailed Tropicbird & $\mathrm{F}=0.03$ & 0.858 & --- & $F=5.26$ & 0.034 & Ari $<$ Cou & $F=31.65$ & 0.000 & Ari $>$ Cou \\
\hline Lesser Noddy & $\mathrm{F}=5.56$ & 0.030 & Ari $<$ Cou & $\mathrm{F}=1.49$ & 0.237 & --- & $F=-3.79$ & 0.000 & Ari $>\mathrm{Cou}$ \\
\hline White Tern & $\mathrm{F}=0.15$ & 0.710 & --- & $F=0.05$ & 0.380 & --- & $F=-0.170$ & 0.865 & --- \\
\hline
\end{tabular}





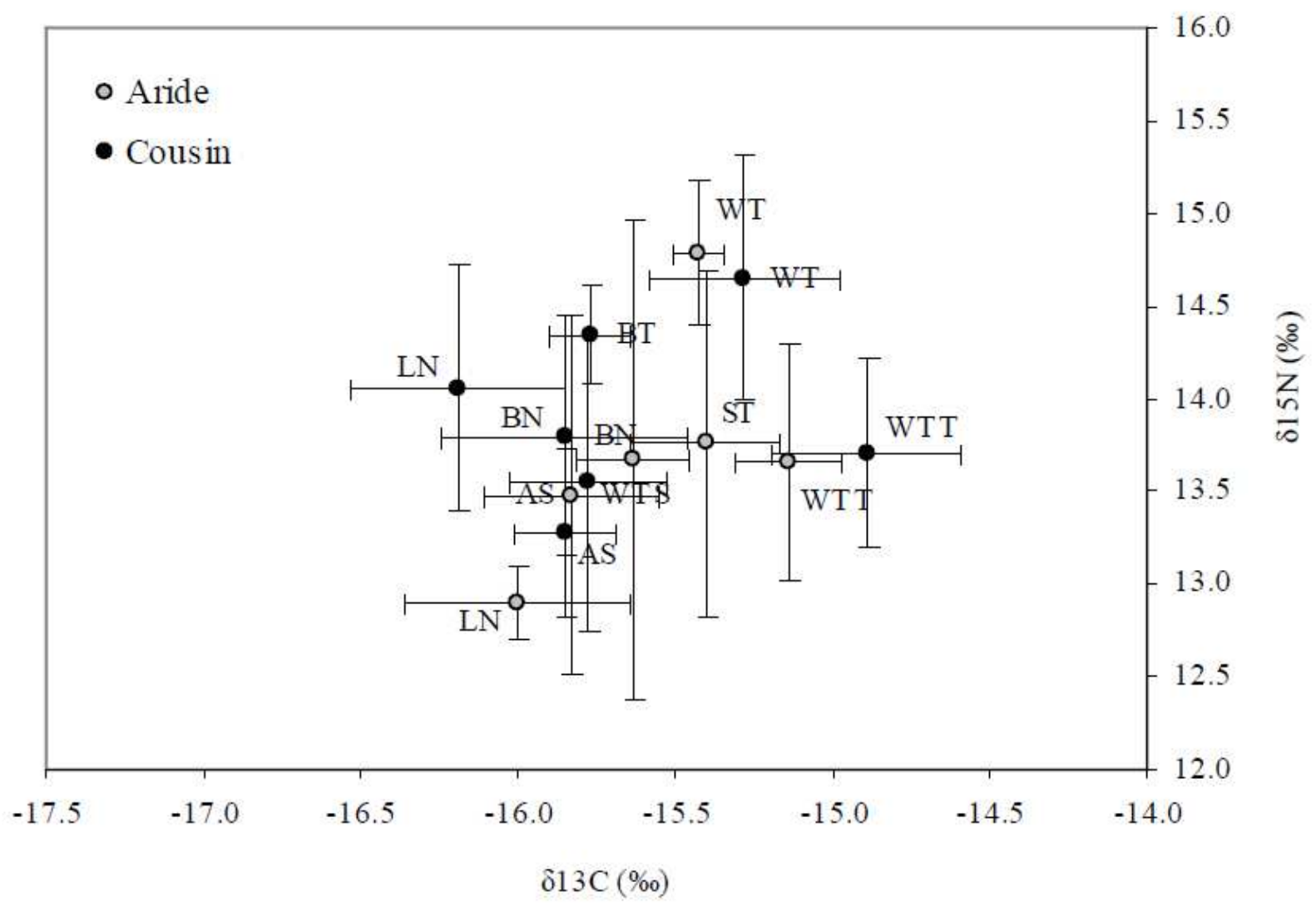

Figure 1. Stable nitrogen and carbon isotope signatures (mean \pm SD) for body feathers of adult seabirds sampled during the southeast monsoon on Aride and Cousin Islands. WTS = wedge-tailed shearwater, AS = Audubon's shearwater, WTT $=$ whitetailed tropicbird, $\mathrm{BN}=$ brown noddy, $\mathrm{LN}=$ lesser noddy, $\mathrm{WT}=$ white tern, $\mathrm{ST}=$ sooty tern and BT $=$ bridled tern. 


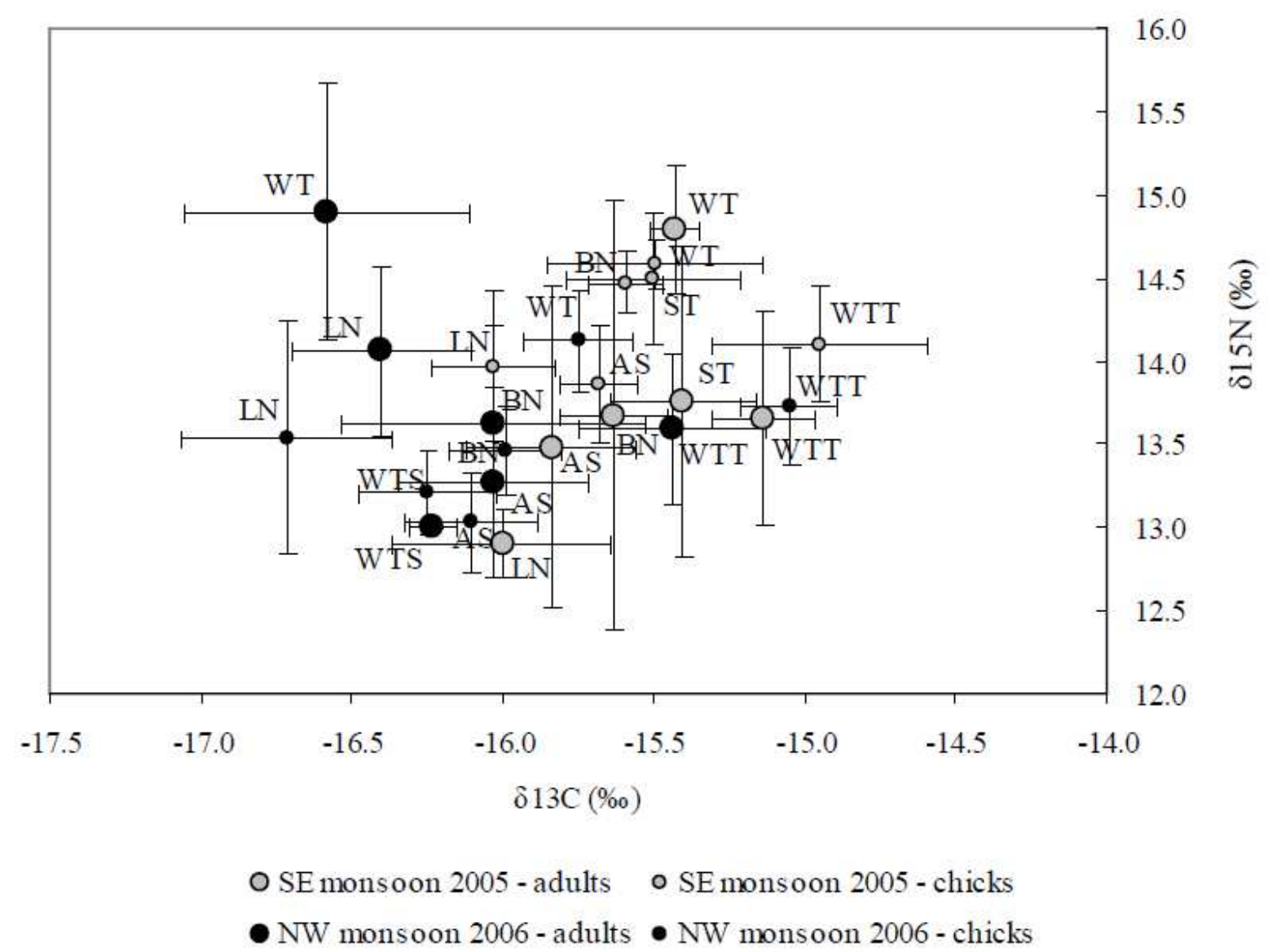

Figure 2. Stable nitrogen and carbon isotope signatures (mean \pm SD) for body feathers of adult and chick seabirds sampled during the southeast and northwest monsoons on Aride Island. AS = Audubon's shearwater, WTT = white-tailed tropicbird, $\mathrm{BN}=$ brown noddy, $\mathrm{LN}=$ lesser noddy and $\mathrm{WT}=$ white tern. 


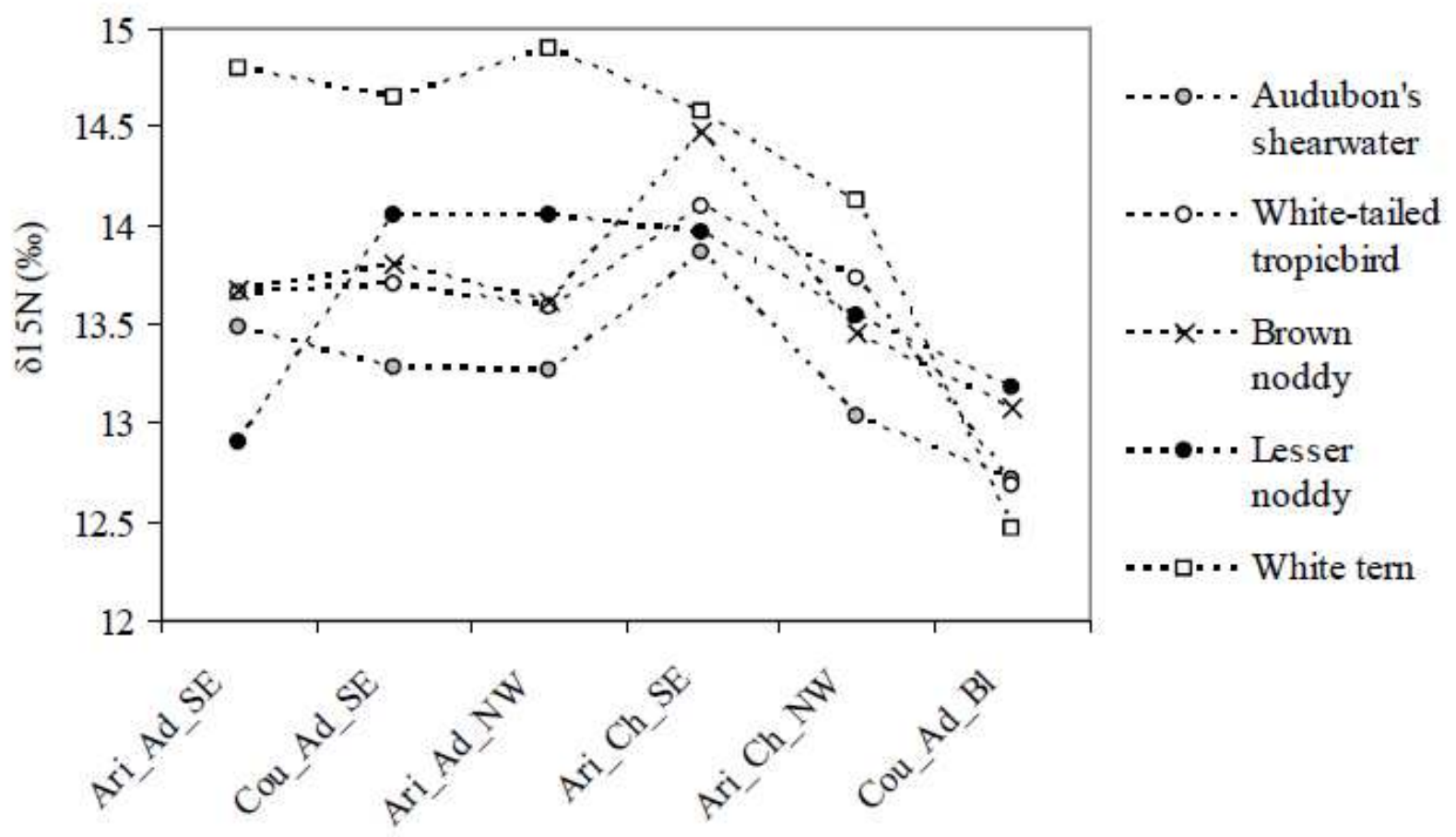

Figure 3. Comparison of nitrogen isotope ratios $\left(\delta^{15} \mathrm{~N}(\%)\right)$ between five seabird species in relation to island, age, season and tissue sampled. Ari = Aride Island, Cou = Cousin Island, $\mathrm{Ad}=$ adult, $\mathrm{Ch}=$ chick, $\mathrm{SE}=$ southeast monsoon, $\mathrm{NW}=$ northwest monsoon and $\mathrm{Bl}=$ blood. 


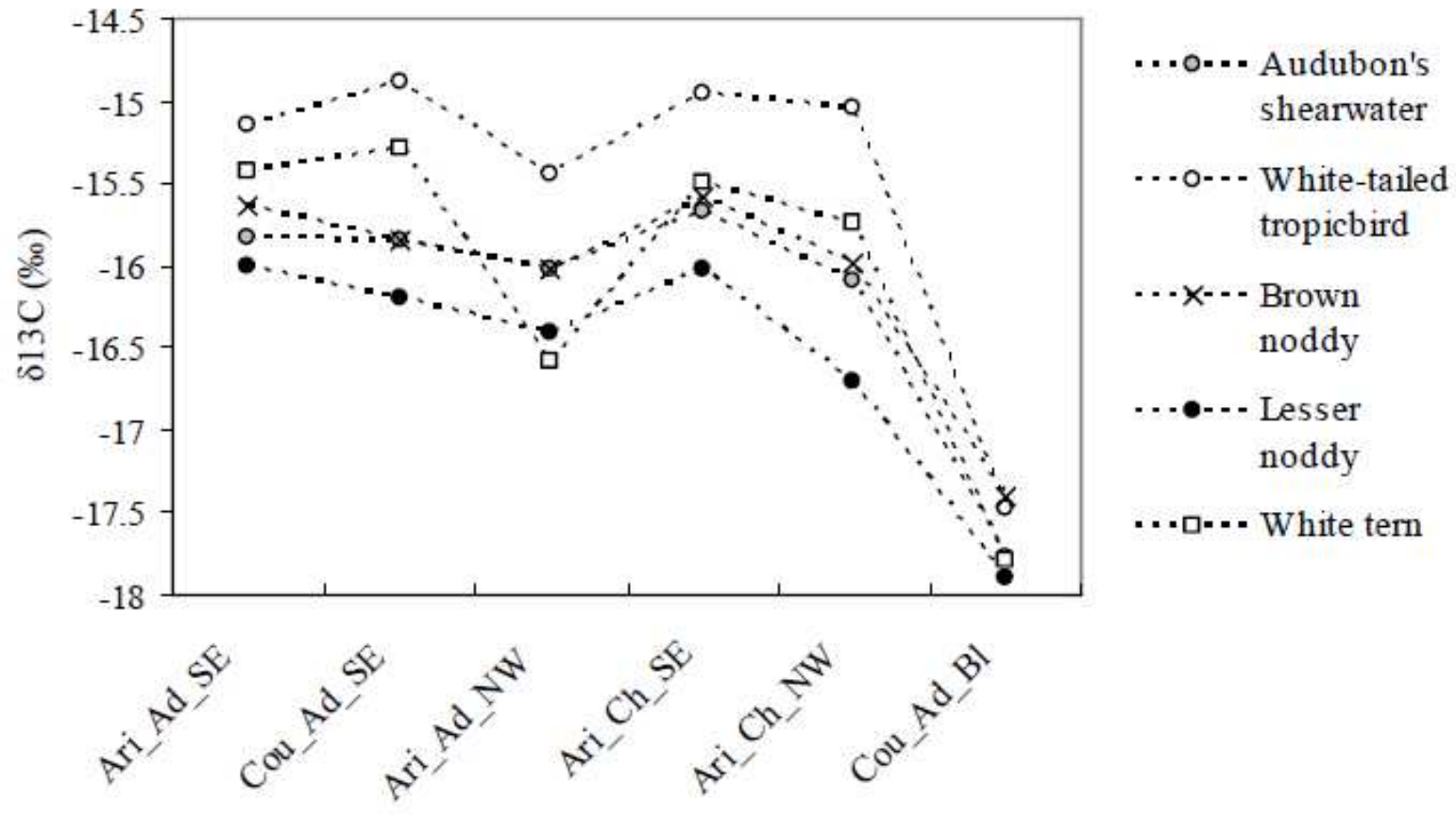

Figure 4. Comparison of carbon isotope ratios $\left(\delta^{13} \mathrm{C}(\%)\right)$ between five seabird species in relation to island, age, season and tissue sampled. Ari $=$ Aride Island, Cou = Cousin Island, $\mathrm{Ad}=$ adult, $\mathrm{Ch}=$ chick, $\mathrm{SE}=$ southeast monsoon, $\mathrm{NW}=$ northwest monsoon and $\mathrm{Bl}=$ blood . 


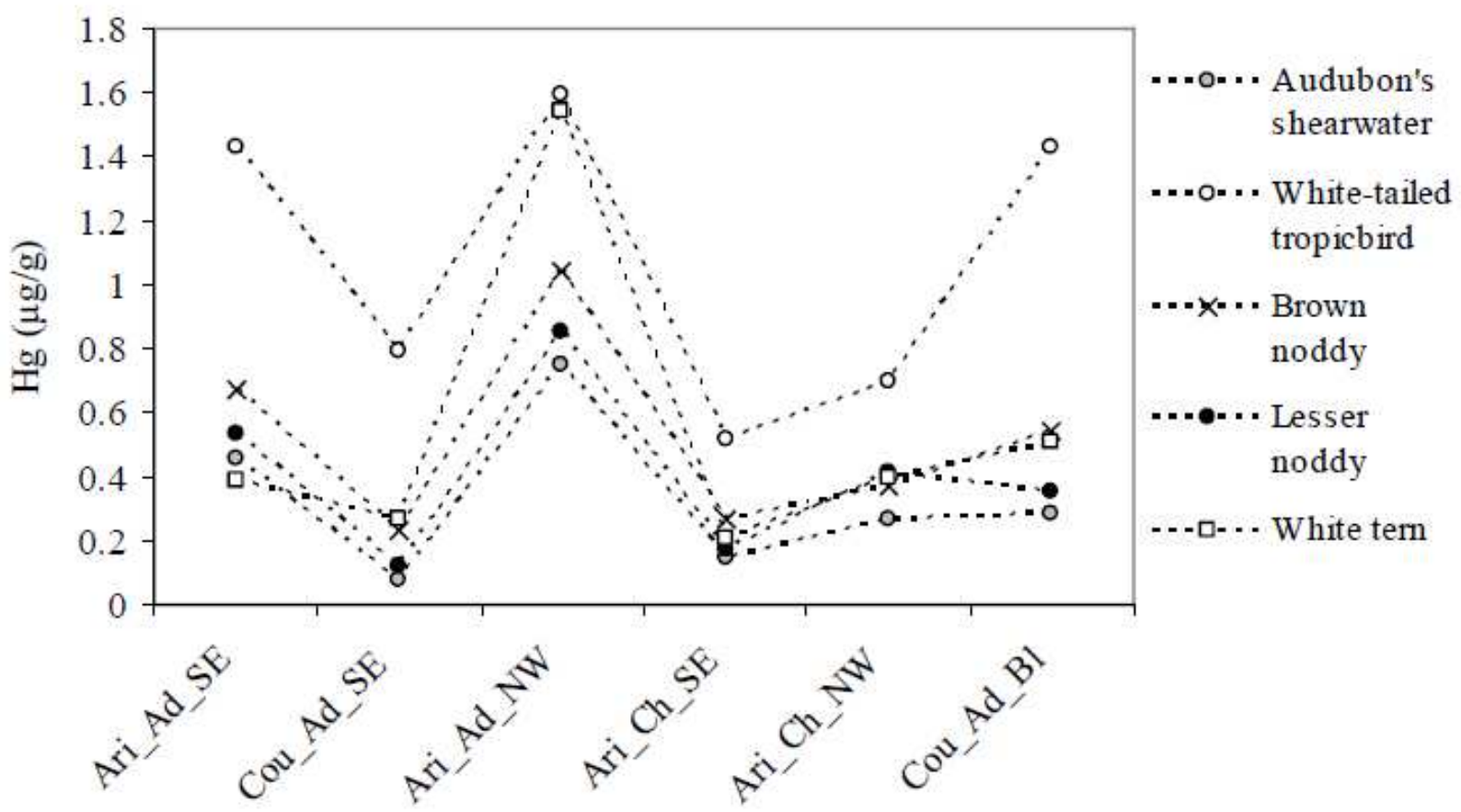

Figure 5. Comparison of mercury $(\mathrm{Hg})$ levels $\left(\mu \mathrm{g} \cdot \mathrm{g}^{-1} \mathrm{dwt}\right)$ between five seabird species in relation to island, age, season and tissue sampled. Ari $=$ Aride Island, $\mathrm{Cou}=$ Cousin Island, $\mathrm{Ad}=$ adult, $\mathrm{Ch}=$ chick, $\mathrm{SE}=$ southeast monsoon, $\mathrm{NW}=$ northwest monsoon and $\mathrm{Bl}=$ blood. 


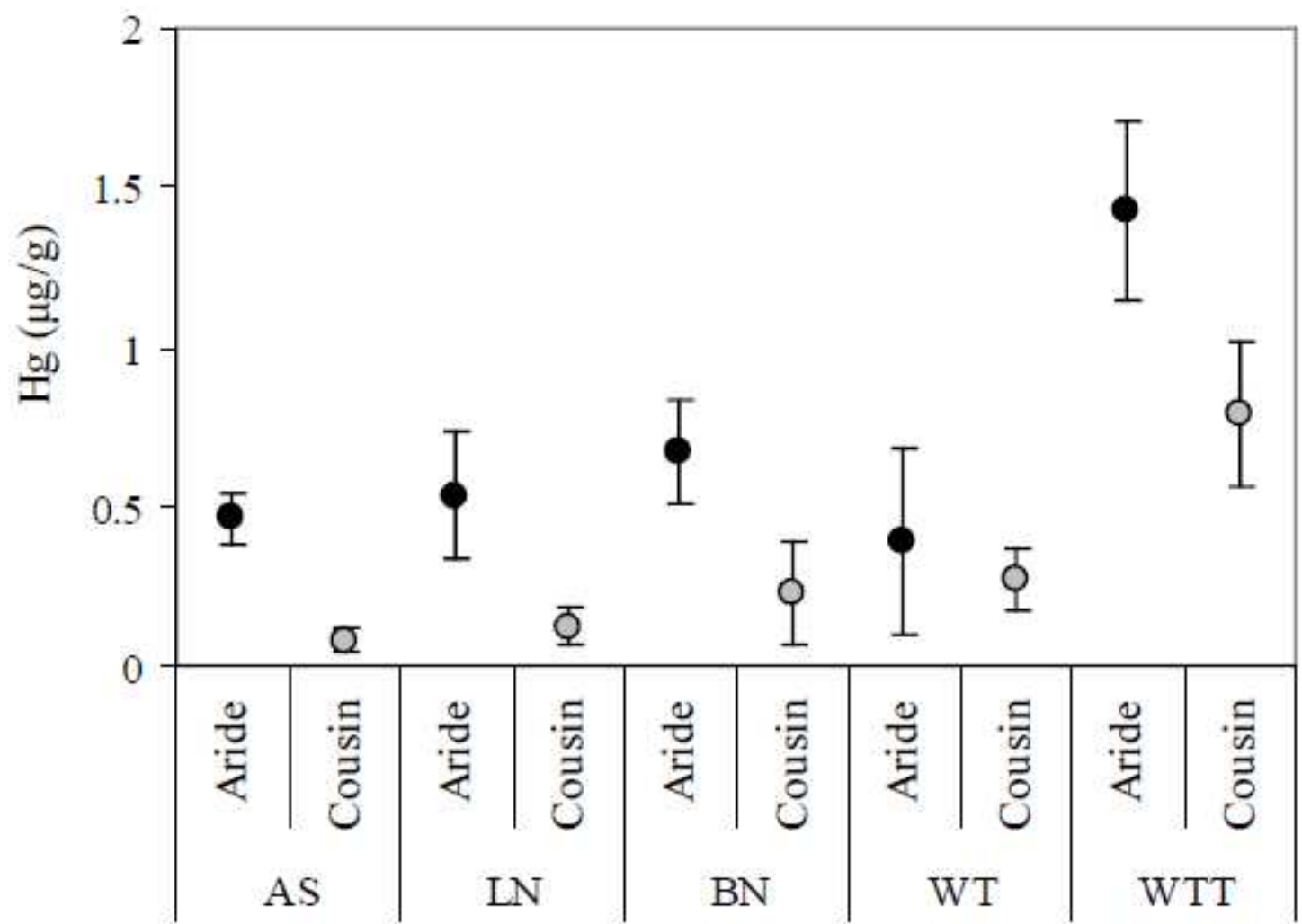

Figure 6. Mercury levels $\left(\mu \mathrm{g} \cdot \mathrm{g}^{-1} \mathrm{dwt}\right.$ ) in body feathers of adult seabirds sampled during the southeast monsoon on Aride and Cousin Islands. Abreviations : AS = Audubon's shearwater, $\mathrm{LN}=$ lesser noddy, $\mathrm{BN}=$ brown noddy, $\mathrm{WT}=$ white tern and WTT $=$ white-tailed tropicbird. Mercury levels are sgnificantly higher on Aride Island for all species except white tern (see text). 